\title{
PENERAPAN MODEL PEMBELAJARAN QUANTUM TEACHING UNTUK MENINGKATKAN PEMAHAMAN KONSEP SISWA PADA PEMBELAJARAN IPA DI SEKOLAH DASAR
}

\author{
Wahyu Winarto \\ STKIP Subang \\ wahyuwinarto25@student.upi.edu
}

\begin{abstract}
The background of the problem in this study is the students' low understanding of concepts in science learning in elementary schools. Researchers have an alternative to solve this problem, namely by applying the Quantum Teaching learning model. Because Quantum Teaching is changing the various interactions that exist in and around the learning moment. These interactions include elements of effective learning that influence student success. These interactions change students 'natural abilities and talents into useful light for themselves and for others, so that they are expected to increase students' understanding of concepts. The formulation of the research problem is how the implementation of science learning by applying the Quantum Teaching learning model and whether the Quantum Teaching learning model can improve students' conceptual understanding in science learning. The purpose of this research is to find out how much the application of the Quantum Teaching learning model can improve students' conceptual understanding of science learning in elementary schools. The research method used was Classroom Action Research (PTK) using Kemmis \& Mc Taggart's research model. Where there are four stages that must be carried out, namely planning, implementing, observing and reflecting.
\end{abstract}

Keywords: Natural Sciences (IPA), Quantum Teaching, Concept Understanding.

\begin{abstract}
ABSTRAK
Latar belakang masalah dalam penelitian ini adalah rendahnya pemahaman konsep siswa pada pembelajaran IPA di Sekolah Dasar. Peneliti mempunyai alternatif untuk menyelesaikan permasalah tersebut yaitu dengan menerapkan model pembelajaran Quantum Teaching. Karena Quantum Teaching adalah pengubahan bermacam-macam interaksi yang ada di dalam dan disekitar momen belajar. Interaksi-interaksi ini mencakup unsur-unsur belajar efektif yang mempengaruhi kesuksesan siswa. Interaksi-interaksi ini mengubah kemampuan dan bakat alamiah siswa menjadi cahaya yang bermanfaat bagi mereka sendiri dan bagi orang lain, sehingga diharapkan mampu meningkatkan pemahaman konsep siswa. Rumusan masalah penelitian ini adalah bagaimanakah pelaksanaan pembelajaran IPA dengan menerapkan model pembelajaran Quantum Teaching dan apakah model pembelajaran Quantum Teaching dapat meningkatkan pemahaman konsep siswa dalam pembelajaran IPA. Adapun tujuan penelitian ini untuk mengetahui seberapa besar penerapan model
\end{abstract}


pembelajaran Quantum Teaching dapat meningkatkan pemahaman konsep siswa pada pembelajaran IPA di Sekolah Dasar. Metode penelitian yang digunakan adalah Penelitian Tindakan Kelas (PTK) dengan menggunakan model penelitian Kemmis \& Mc Taggart. Dimana ada empat tahapan yang harus dilakukan yaitu perencanaan, pelaksanaan, pengamatan dan refleksi.

Kata Kunci : Ilmu Pengetahuan Alam (IPA), Quantum Teaching, Pemahaman Konsep.

\section{A. Pendahuluan}

Pendidikan adalah usaha sadar terencana untuk mewujudkan suasana belajar dan proses pembelajaran agar peserta didik secara aktif mengembangkan potensi dirinya untuk memiliki kekuatan spiritual keagamaan, pengendalian diri, kepribadian, kecerdasan, akhlak mulia, serta keterampilan yang diperlukan dirinya dan masyarakat. (Priatna, 2013: 1).

$$
\text { Tujuan setiap proses }
$$

pembelajaran adalah diperolehnya hasil yang optimal. Hal ini akan dicapai apabila semua terlibat secara aktif baik fisik, mental, maupun emosional. Pembelajaran merupakan penentu dalam keberhasilan pendidikan yang diharapkan. $\mathrm{Di}$ Sekolah Dasar (SD) terdapat berbagai bidang studi yang harus di ajarkan kepada siswa, salah satunya yaitu bidang studi IImu Pengetahuan Alam (IPA).
Untuk menciptakan proses pembelajaran yang aktif, pembelajaran IPA harus menekankan pada pengalaman langsung yang mampu melibatkan keaktifan siswa. Baik aktivitas fisik maupun aktivitas mental dan berfokus pada siswa, yang berdasarkan pada pengalaman keseharian siswa dan minat siswa. Seperti yang diungkapkan Piaget (dalam Samatowa, 2010 :5) yang menyatakan bahwa" pengalaman langsung memegang peranan penting sebagai pendorong lajunya perkembangan kognitif anak". Pengalaman langsung anak terjadi secara spontan dari kecil (sejak lahir) sampai usia 12 tahun, yang mana pada rentang usia 6 sampai 12 tahun merupakan usia anak SD.

Namun pada kenyataannya, mata pelajaran IPA di SD dirasakan sebagai pelajaran yang berorientasi pada hapalan semata. Siswa kurang terlibat aktif dalam pembelajaran karena siswa hanya melakukan 
aktivitas minds on yaitu duduk, diam, mencatat, dan menghafal. Guru tidak menuntun siswa untuk menemukan konsep sendiri, padahal konsep merupakan dasar atau landasan untuk melakukan proses penemuan yang nantinya akan memunculkan konsep-konsep baru bagi diri siswa.

Selain itu, menurut penelitian yang telah dilakukan oleh Setyastuti (2013), dalam pembelajaran IPA guru jarang menggunakan media atau alat peraga, sekalipun di sekolah ada beberapa alat yang disediakan. Kurang terampilnya guru dalam mengoptimalkan media dan alat peraga membuat siswa kurang mendapatkan pengalaman dalam melakukan kegiatan percobaan sehingga keterampilan siswa dalam menemukan konsep terbilang rendah. Kemampuan yang dimiliki siswa ratarata didapat dari proses menghapal bukan dari proses pemahaman. Keadaan tersebut merupakan salah satu faktor belum optimalnya hasil belajar siswa yang mengindikasikan pemahaman konsep siswa yang masih rendah. Hal tersebut juga terbukti setelah melakukan analisis terhadap soal dan jawaban siswa, ternyata hampir seluruh siswa masih merasa kesulitan untuk menjawab pertanyaan pada soal mengukur aspek pemahaman (C2) seperti menjelaskan, mencontohkan, menginterpretasi dan mengklasifikasi. Atas dasar permasalahan tersebut, peneliti mencoba memberikan alternatif pemecahaan masalah dengan memperbaiki proses pembelajaran IPA di kelas agar memberikan pengalaman langsung kepada siswa serta melibatkan siswa dengan aktif. Sebagai upaya meningkatkan konsep siswa, sehingga hasil pembelajaran pun meningkat. Model pembelajaran yang dapat diterapkan adalah Quantum Teaching.

\section{B. Metode Penelitian}

Metode yang digunakan dalam penelitian ini adalah metode kuantitatif, karena penelitian ini dimulai dari hipotesis, kemudian dibuktikan melalui pengumpulan data di lapangan sehingga dapat ditarik suatu kesimpulan dari variabel yang diteliti. Peneliti menggunakan konsep dan teori untuk merumuskan hipotesis. Penelitian kuantitatif adalah penelitian yang digunakan untuk mencari pengaruh perlakuan tertentu 
terhadap yang lain dalam kondisi yang terkendali.

Desain yang digunakan dalam penelitian ini adalah desain kuasi eksperimen (quasi experiment design) dengan jenis desain kelompok control (non-equivalent control group design). Pada penelitian ini subjek tidak dikelompokan secara acak, akan tetapi peneliti menerima keadaan subjek seadanya. Kelompok penelitiannya terdiri dari dua yaitu kelas eksperimen melakukan pembelajaran dengan metode sosiodrama berorientasi kecerdasan emosional dan kelas kontrol melakukan pembelajaran langsung sesuai programnya. Pada pelaksanaannya, penelitian ini terdapat tes awal (pretest), perlakuan yang berbeda (treatment), dan tes akhir (posttest).

\section{Hasil Penelitian dan Pembahasan}

1. Pengertian IImu Pengetahuan Alam (IPA)

Menurut Samatowa (2010: 1) IImu pengetahuan Alam (IPA) atau sains dalam arti sempit sebagai disiplin ilmu dari "physical sciences dan life sciences" . Menurut Darmojo (dalam Samatowa, 2010: 2) ' IPA adalah pengetahuan yang rasional dan objektif tentang alam semesta dan segala isinya'. IPA membahas tentang gejala-gejala alam yang disusun secara sistematis yang didasarkan pada hasil percobaan dan pengamatan yang dilakukan oleh manusia.

\section{Menurut Powler (dalam} Samatowa, 2010: 3) bahwa 'IPA merupakan ilmu yang berhubungan dengan gejala alam dan kebendaan yang sistematis yang tersusun secara teratur, berlaku umum yang berupa kumpulan dari hasil observasi dan eksperimen sistematis (teratur)'. Artinya, pengetahuan itu tersusun dalam suatu sistem, tidak berdiri sendiri, satu dengan yang lainnya saling berkaitan, saling menjelaskan sehingga seluruhnya merupakan satu kesatuan yang utuh.

Menurut Susanto (2013: 167), IPA atau Sains adalah usaha manusia dalam memahami alam semesta melalui pengamatan yang tepat pada sasaran, serta menggunakan prosedur, dan dijelaskan dengan penalaran sehingga mendapatkan suatu kesimpulan. 
Samatowa

(2010:

4)

mengungkapkan IPA melatih anak berfikir kritis dan objektif. Pengetahuan yang benar artinya pengetahuan yang dibenarkan menurut tolak ukur kebenaran ilmu, yaitu rasional dn objektif. Rasional artinya masuk akal atau logis, diterima oleh akal sehat. Objektif artinya sesuai dengan objeknya, sesuai dengan kenyataan atau sesuai dengan pengalaman, pengamatan melalui panca indera.

Menurut Piaget (dalam Susanto, 2013: 170) mengatakan bahwa anak usia sekolah dasar yang berkisar antara 6 atau 7 tahun sampai 11 atau 12 tahun masuk dalam kategori fase operasional konkret.

Terdapat beberapa alasan yang menyebabkan mata pelajaran IPA dimasukan ke dalam kurikulum sekolah yaitu sebagai berikut.

a. Bahwa IPA berfaedah bagi suatu bangsa. Karena kesejahteraan materil suatu bangsa banyak sekali bergantung pada kemampuan bangsa itu dalam bidang IPA, sebab IPA merupakan dasar teknologi dan disebut-sebut sebagai tulang punggung pembangunan. Pengetahuan dasar untuk teknologi ialah IPA. Orang tidak menjadi insinyur elektronika yang baik, atau dokter yang baik, tanpa dasar yang cukup luas mengenai ilmu pengetahuan alam.

b. Bila diajarkan IPA menurut cara yang tepat, maka IPA merupakan suatu pelajaran yang melatih atau mengembangkan kemampuan berfikir kritis.

c. Bila IPA diajarkan melalui percobaan-percobaan yang dilakukan sendiri oleh anak, maka IPA tidak hanya merupakan mata pelajaran yang bersifat hafalan semata.

d. Mata pelajaran IPA mempunyai nilai-nilai pendidikan yaitu dapat membentuk kepribadian anak secara keseluruhan. (Samatowa, 2010: 6).

\section{Model pembelajaran Quantum}

\section{Teaching}

Menurut DePorter (2010: 34) Kata Quantum berarti interaksi yang mengubah energi menjadi cahaya. Dengan demikian Quantum Teaching adalah pengubahan bermacammacam interaksi yang ada di dalam dan disekitar momen belajar. Interaksi-interaksi ini mencakup 
unsur-unsur belajar efektif yang mempengaruhi kesuksesan siswa. Interaksi-interaksi ini mengubah kemampuan dan bakat alamiah siswa menjadi cahaya yang bermanfaat bagi mereka sendiri dan bagi orang lain.

Model pembelajaran Quantum Teaching memiliki asas utama yaitu "Bawalah dunia mereka ke dunia kita dan antarkan dunia kita ke dunia mereka" (DePorter, 2010: 34).

Quantum Teaching memiliki lima prinsip yang harus diketahui oleh seorang guru. Prinsip-prinsip ini mempengaruhi seluruh aspek Quantum Teaching. Menurut DePorter (2010: 36), prinsip-prinsip tersebut diantaranya "segalanya berbicara, segalanya bertujuan, pengalaman sebelum pemberian nama, akui setiap usaha dan jika layak dipelajari, maka layak pula dirayakan".

Dalam melakukan pembelajaran Quantum Teaching dengan enam langkah yang tercermin dalam istilah TANDUR (DePorter, 2010: 127), yaitu

a. Tumbuhkan, pada tahap ini tumbuhkan minat belajar siswa dengan memuaskan rasa ingin tahu siswa dalam bentuk: "Apakah manfaatnya BAgiKu (AMBAK)". Tumbuhkan suasana yang menyenangkan di hati siswa, dalam suasana relaks, tumbuhkan interaksi dengan siswa, masuklah ke alam pikiran mereka dan bawalah alam pikiran mereka kedalama pikiran kita, yakinkan siswa mengapa harus mempelajari ini dan itu, sehingga siswa mengalami bahwa belajar adalah suatu kebutuhan bukan suatu keharusan.I

b. Alami, pada tahap ini, ciptakan atau datangkan pengalaman umum yang dapat di mengerti semua siswa.

c. Namai, setelah siswa mengalami pengalaman belajar pada kompetensi dasar tertentu, siswa dibimbing untuk memberikan identitas, menemukan konsep yang dibangun atas pengetahuan dan keingintahuan pada saat itu.

d. Demonstrasikan, siswa akan mampu mengingat 90\% jika siswa mendengar, melihat, dan melakukan, maka dari itu pula langkah demonstrasi ini siswa diberi kesempatan kepada mereka 
untuk mendemostrasikan kemampuannya.

e. Ulangi, kegiatan pengulangan memperkuat koneksi saraf dan membuktikan rasa "Aku tahu bahwa aku tahu ini!". Sehingga siswa akan teringat apa yang dipelajari.

f. Rayakan, perayaan adalah ekspresi dari kelompok seseorang yang telah berhasil mengerjakan suatu tugas atau kewajiban dengan baik.

\section{Pemahaman Konsep}

Menurut Bloom (dalam Susanto, 2013: 6), 'Pemahaman diartikan sebagai kemampuan untuk menyerap arti dari materi atau bahan yang dipelajari.' Pemahaman menurut Bloom ini adalah seberapa besar siswa mampu menerima, menyerap dan memahami pelajaran yang diberikan oleh guru kepada siswa atau sejauh mana siswa dapat memahami dan mengerti apa yang ia baca, yang ia lihat, yang ia alami atau yang ia rasakan berupa hasil penelitian atau observasi langsung yang ia lakukan.

Sedangkan konsep ialah "kemampuan untuk mengadakan diskriminasi antar golongan-golongan objek dan sekaligus mengadakan generalisasi dengan mengelompokan objek-objek yang mempunyai satu atau lebih ciri yang sama" (Widodo, 2010: 27). Secara sederhana konsep dapat diartikan sebagai penanaman (pemberian label) untuk sesuatu yang membuat seseorang mengenal, mengerti, memahami tentang sesuatu tersebut. Konsep merupakan pemberian tanda pada sesuatu objek untuk membantu seseorang mengerti dan paham akan tanda terhadap objek tersebut.

"Konsep dibedakan atas konsep konkrit dan konsep yang harus didefinisikan" (Widodo, 2010: 27). Konsep konkret adalah pengertian yang menunjuk pada objek-objek dalam lingkungan fisik. Sedangkan konsep yang didefinisikan adalah konsep yang mewakili realitas hidup, tetapi tidak langsung menunjuk pada realitas dalam lingkungan fisik karena realitas itu tidak bermateri. Realitas tidak bermateri tidak dapat diamati secara langsung.

Menurut Bloom (dalam Kesuma 2011: 26), ada tujuh kategori pemahaman yang berhubungan dengan penguasaan konsep, diantaranya sebagai berikut: 
Menginterpretasi, mencontohkan, mengklasifikasi, mengikhtisarkan, menyimpulkan, membandingkan dan mengeksplanasi.

\section{Langkah-langkah Pembelajaran}

Pembelajaran IPA di Kelas V dengan menggunakan Model Pembelajaran Quantum Teaching.

Tabel 1 Langkah-langkah Pembelajaran IPA dengan Menggunakan

Model Quantum Teaching

\begin{tabular}{|c|c|c|}
\hline & $\begin{array}{c}\text { Fase } \\
\text { Pembelajaran }\end{array}$ & Kegiatan Pembelajaran \\
\hline $\begin{array}{l}\text { Pendahuluan } \\
\text { (Apersepsi/ } \\
\text { Motivasi) }\end{array}$ & Tumbuhkan & $\begin{array}{l}\text { - Membuka pelajaran dengan memberikan salam dan } \\
\text { berdo'a bersama. } \\
\text { - Guru membimbing siswa untuk menyanyikan lagu } \\
\text { - } \quad \text { Guro mengecek kebersihan kelas dan mengabsen } \\
\text { kehadiran siswa. } \\
\text { - Guru mengondisikan siswa kedalam situasi belajar } \\
\text { dengan cara mengatur tempat duduk siswa dan } \\
\text { memastikan siswa siap untuk belajar. } \\
\text { - Guru memotivasi siswa sebelum memulai pembelajaran, } \\
\text { guru mengajak siswa menggerakan tangan membentuk } \\
\text { - } \text { Guruf ( COCONUT) bersama-sama. } \\
\text { - Guru menyampaikan tujuan pembelajaran. } \\
\text { ajarkan "Apa yang terjadi apabila dalam kehidupan tidak } \\
\text { ada makanan?" }\end{array}$ \\
\hline \multirow{5}{*}{$\begin{array}{l}\text { Kegiatan inti } \\
\text { (Eksplorasi) }\end{array}$} & Alami & $\begin{array}{l}\text { - } \quad \text { Guru menempelkan salah saru gambar burung. } \\
\text { - } \quad \text { Siswa diminta menyebutkan nama jenis burung tersebut. } \\
\text { - } \quad \text { Guru bertanya kepada siswa " bagaimana bentuk paruh } \\
\text { - } \quad \text { Siswa menanggapi pertanyaan tersebut. } \\
\text { - } \quad \text { Guru menempelkan gambar selanjutnya } \\
\text { - Guru dan siswa melakukan tanya jawab } \\
\text { - Guru menjelaskan materi mengenai beberapa jenis } \\
\text { burung. }\end{array}$ \\
\hline & \multirow[b]{2}{*}{ Namai } & $\begin{array}{l}\text { - Guru meminta salah satu siswa untuk menuliskan jenis } \\
\text { burung yang ada pada gambar. } \\
\text { - Siswa menanggapi perintah guru. }\end{array}$ \\
\hline & & $\begin{array}{l}\text { - } \quad \text { Guru menempelkan gambar jenis kaki burung } \\
\text { - } \quad \text { Guru bertanya "pada gambar } 1 \text { merupakan kaki jenis } \\
\text { - } \quad \text { Siswa menanggapi perintah guru } \\
\text { - } \quad \text { Guru menyuruh satu orang siswa untuk menulis kedepan. } \\
\text { - } \quad \text { Guru menjelaskan materi mengenai jenis kaki burung. }\end{array}$ \\
\hline & Demonstrasi & $\begin{array}{l}\text { - } \quad \text { Siswa dibagi menjadi empat kelompok. } \\
\text { - } \quad \text { Guru membagikan LKS kepada setiap kelompok kerja } \\
\text { siswa. } \\
\text { - } \quad \begin{array}{l}\text { Guru memberikan penjelasan cara pengisian LKS. } \\
\text { - Siswa dibimbing guru mengerjakan LKS dengan } \\
\text { bekerjasama. }\end{array}\end{array}$ \\
\hline & & $\begin{array}{l}\text { - Siswa diminta mendiskusikan jawaban dari pertanyaan } \\
\text { yang terdapat pada LKS. }\end{array}$ \\
\hline
\end{tabular}




\begin{tabular}{|c|c|c|}
\hline (Elaborasi) & & $\begin{array}{llccc}\text { - } & \text { Guru menyuruh satu orang siswa } & \text { untuk } \\
\text { mempresentasikan hasil kerjanya di depan kelas. } & \end{array}$ \\
\hline \multirow{3}{*}{$\begin{array}{l}\text { Penutup } \\
\text { (Konfirmasi) }\end{array}$} & Ulangi & $\begin{array}{l}\text { - Guru memerikan umpan balik terhadap proses } \\
\text { pembelajaran } \\
\text { - Guru memberikan penguatan materi mengenai : } \\
\text { penyesuaian hewan untuk memperoleh makanan. } \\
\text { - Siswa bersama guru menyimpulkan materi penyesuaian } \\
\text { hewan memperoleh makanan. }\end{array}$ \\
\hline & Rayakan & $\begin{array}{l}\text { - Guru membimbing siswa untuk menyanyikan lagu lihat } \\
\text { kebun ku. } \\
\text { - Guru memberikan reward kepada siswa yang aktif } \\
\text { selama proses pembelajaran. }\end{array}$ \\
\hline & & $\begin{array}{l}\text { - } \quad \text { Guru memberikan soal evaluasi } \\
\text { - Siswa diminta mengerjakan soal evaluasi. } \\
\text { - Guru menyampaikan materi pembelajaran untuk } \\
\text { pertemuan selanjutnya. } \\
\text { - Siswa bersama guru berdo'a untuk mengakhiri } \\
\text { pembelajaran. } \\
\text { - Guru menutup pelajaran. }\end{array}$ \\
\hline
\end{tabular}

\section{Kesimpulan}

Berdasarkan kajian pustaka ini dapat disimpulkan bahwa, untuk meningkatkan pemahaman konsep siswa pada pembelajaran IPA dapat dilakukan dengan penerapan Model Pembelajaran Quantum Teaching. Pembelajaran dengan menggunakan Model Pembelajaran Quantum Teaching membuat pembelajaran lebih menyenangkan serta bermakna karena siswa lebih aktif selama proses pembelajaran. Dengan demikian penerapan Model Pembelajaran Quantum Teaching ini diharapkan dapat meningkatkan pemahaman konsep siswa.

\section{DAFTAR PUSTAKA}

Priatna, A. (2013). Panduan Menuju Sekolah Bermutu. Bandung: Nurani Press.

Samatowa, U. (2010). Pembelajaran IPA di Sekolah Dasar. Jakarta: PT Indeks.

DePorter, B. (2010). Quantum Teaching. Bandung: KAIFA.

Susanto, A. (2013). Teori Belajar Pembelajaran di Sekolah Dasar.Jakarta:Kencana Prenada Media Group.

Widodo, A , Wuryastuti, S, \& Margareta. (2010). Pendidikan IPA SD.Bandung: UPI PRESS.

Kesuma, D., \& Salimi, M. (2011). Indikator Capaian Kompetensi Pedoman dan Teori Rencana Pelaksanaan Pembelajaran (Bahan Ajar Mata Kuliah Perencanaan Pembelajaran 
Sekolah Dasar). Bandung : Tidak diterbitkan.

Sari, G.P. (2014). Penerapan Model Quantum Teaching Melalui Media Kartu Domino untuk Meningkatkan Pemahaman Konsep Bilangan Romawi Siswa Kelas IV SDN VII Baturetno. (Tesis). Universitas Sebelas Maret. Semarang.

Setyastuti, D. (2013). Penerapan Model Pembelajaran Kooperatif Tipe Snowball Throwing pada Mata Pelajaran IPA Materi Proses Daur Air untuk Meningkatkan Hasil Belajar Siswa. (Skripsi). Fakultas IImu Pendidikan. Universitas Pendidikan Indonesia. Bandung. 